\title{
EMPLOYING FINANCIAL ACCOUNTING STANDARDS FOR ENTITIES WITHOUT PUBLIC ACCOUNTABILITY FOR AUDITING
}

\author{
Akie Rusaktiva \\ Adri Putra Nugraha \\ Accounting Department Faculty of Economics and Business \\ Brawijaya University, Jl. M.T. Haryono 165 Malang \\ No Telepon:08123352564, emai:manunggal102@yahoo.com \\ No Telepon:08566109909, email:putra_adri@yahoo.com
}

\begin{abstract}
Financial Accounting Standards for Entities Without Public Accountability (FAS-EWPA) is a financial accounting standards issued by The Indonesian Institute of Accountants or Ikatan Akuntan Indonesia (IAI) and endorsed by the Financial Accounting Standards Board of Indonesian Accountants or Dewan Standar Akuntansi Keuangan Ikatan Akuntan Indonesia (DSAK IAI) and intended for small and medium enterprises. The underlying priciple of IAI in issuing this particular standards is the attempt to facilitate small and medium enterprises in arranging their financial reports. If this standard is not issued, they have to follow the new FAS (which is stage of adopting IFRS - full convergence 2012) to arrange their financial reports. The application of this FAS-EWPA based IFRS is relatively more complex and expensive for small and medium enterprises. FAS-EWPA adopted some parts of IFRS (International Financial Reporting Standards) for small-medium enterprises (IFRS for SmallMedium-sized Entities/SMEs). This study aims to describe the layout of the difference measurement, assessment, report and the implementation of auditing standards between FAS-IFRS and FAS-EWPA. This study employed descriptive qualitative technique of data analysis by reviewing literature and analysing the field concerning with the implementation of Financial Accounting Standards Statements (FASS) and FAS-EWPA. Specifically, the secondary data of this study are FAS-IFRS and FAS-EWPA. The findings shows that there is a difference presentation and disclosure of financial statements between entities which report using FAS-IFRS and FAS-EWPA. Therefore the perceived program and audit procedures will be different because it will be tailored to the presentation and objectives the audit, suppose that in the implementation of FASS and EWPA, there is a difference in the assertions about the disclosure/presentation. For other assertions about existence, completeness, rights and obligations as well as assessment and allocation, basically, between FASS and EWPA, they have a common concept. While in presentation assertions as has been described earlier, the FAS-EWPA has a simpler form than with FASS, therefore there is a definitely difference in terms of the presentation between the two.
\end{abstract}




\section{PENDAHULUAN}

Ikatan akuntan indonesia (IAI) telah meluncurkan Standar Akuntansi Keuangan Entitas Tanpa Akuntabilitas (SAK-ETAP). SAK ETAP ini dimaksudkan untuk entitas tanpa akuntabilitas publik dan membantu perusahaan kecil menengah dalam menyediakan pelaporan keuangan yang tetap relevan dan andal serta diakui oleh berbagai pihak yang membutuhkan (user). SAK-ETAP dimaksudkan untuk digunakan. Entitas tanpa akuntabilitas publik adalah entitas yang (SAK-ETAP 1 par.4-13) Tidak memiliki akuntabiltas publik signifikan dan menerbitkan laporan keuangan untuk tujuan umum (general purpose financial statement) bagi pengguna eksternal.

Entitas memiliki akuntabilitas publik signifikan jika (SAK-ETAP 1 par.14-27):

a. Entitas telah mengajukan pernyataan pendaftaran, atau dalam proses pengajuan pernyataan pendaftaran, pada otoritas pasar modal atau regulator lain untuk tujuan penerbitan efek di pasar modal; atau

b. Entitas menguasai aset dalam kapasitas sebagai fidusia untuk sekelompok besar masyarakat, seperti bank, entitas asuransi, pialang dan atau pedagang efek, dana pensiun, reksa dana dan bank investasi.

Entitas yang memiliki akuntabilitas publik signifikan dapat menggunakan SAK ETAP jika otoritas berwenang membuat regulasi mengizinkan penggunaan SAK-ETAP. Semisal Bank Perkreditan Rakyat yang telah diijinkan oleh Bank Indonesia menggunakan SAK ETAP mulai 1 Januari 2010 sesuai dengan SE No. 11/37/DKBU tanggal 31 Desember 2009. Sedangkan dahulunya BPR memiliki pedoman akuntansi tersendiri yakni pedoman akuntansi BPR.

Salah satu pengguna laporan keuangan ini adalah pihak perbankan. Bank membutuhkan laporan keuangan untuk melakukan analisa atas kondisi keuangan perusahaan dan badan usaha dalam rangka kredit atau peminjaman dana untuk operasional. Perusahaan terutama usaha menengah kecil sangat diperlukan untuk menambah modal kerja yang sudah dimiliki sehingga diperlukan penyusunan laporan keuangan yang dianggap relevan dan reliable.Kebutuhan atas laporan keuangan tidak hanya berhenti pada tataran penyusunan, namun yang lebih dibutuhkan adalah laporan keuangan yang sudah dijustifikasi (audit) oleh pihak eksternal. Auditor merupakan profesi yang ditunjuk oleh pihak yang berkepentingan untuk melakukan justifikasi (audit) atas kewajaran laporan keuangan yang dibuat oleh pihak manajemen.

Dalam melakukan kegiatan audit, seorang auditor menggunakan dua standar dalam menjalaninya yaitu Standar Akuntansi Keuangan (SAK) dan Standar Profesi Akuntan Publik (SPAP). Tujuan dari audit yang dilakukan oleh seorang auditor menurut Boynton (2008) adalah: Existence and Occurence (keberadaan), Completeness (kelengkapan), Rights 
and Obligations (Hak dan Kewajiban), Valuation or Allocation (Penilaian dan Alokasi), Presentation and Disclosure ( Penyajian yang wajar)

Auditor menggunakan SAK selama ini sebagai pedoman pelaksanaan untuk mencapai tujuan audit, dimana SAK yang ada selama ini (terbaru SAK 2007) memang diperuntukkan perusahaan publik, yang memiliki karakteristik sama dengan penjelasan diatas. Ada kesan penggunaan SAK tersebut (SAK-2007) untuk menyusun laporan keuangan perusahaan yang tidak memiliki akuntabilitas publik.

Dengan munculnya SAK-ETAP ini diharapkan bagi profesi auditor untuk dapat menyelaraskan prosedur yang akan dilakukan dalam proses audit. Dalam rangka penyelarasan ini, diperlukan suatu kajian dan penelitian yang hasilnya akan mampu menjawab pertanyaan penelitian ini.

\section{TELAAH LITERATUR}

\section{Proses Audit}

Auditing adalah proses pengumpulan dan pengevaluasian bahan bukti tentang informasi yang dapat diukur mengenai suatu entitas ekonomi yang dilakukan seseorang yang kompeten dan independen untuk dapat menentukan dan melaporkan kesesuaian informasi dimaksud dengan kriteria-kriteria yang telah ditetapkan (Arens \& Leobbecke, 1998) sedangkan menurut Mautz dan Sharaf, 1993 mendefinisikan auditing sebagai rangkaian praktek dan prosedur, metode dan teknik, suatu cara yang hanya sedikit butuh penjelasan, diskripsi, rekonsiliasi dan argumen yang biasanya menggumpal sebagai teori. Selanjutnya Mulyadi \& Kanaka Puradiredja (1998) mendifinisikan auditing adalah proses sistematis untuk mempelajari dan mengevaluasi bukti secara objektip mengenai pernyataanpernyataan tentang kegiatan dan kejadian ekonomi, dengan tujuan untuk menetapkan tingkat kesesuaian antara pernyataan-pernyataan tersebut dengan kriteria yang telah ditetapkan, serta penyampaian hasil-hasilnya kepada pemakai yang berkepentingan. Secara umum tujuan umum audit atas laporan keuangan itu sendiri untuk menyatakan pendapat atas kewajaran laporan keuangan, dalam semua hal yang material, sesuai dengan prinsip akuntansi berterima umum di Indonesia. Kewajaran laporan keuangan dinilai berdasarkan asersi yang terkandung dalam setiap unsur yang disajikan dalam laporan keuangan. Asersi merupakan pernyataan manajemen.

Dari definisi di atas, dapat ditarik kesimpulan bahwa proses auditing meliputi:

1. Objek pemeriksaan adalah laporan keuangan yang disusun oleh manajemen beserta catatan-catatan pembukuan dan bukti-bukti pendukungnya.

2. Pemeriksaan dilakukan secara kritis dan sistematis. 
Dalam melakukan pemeriksaan, akuntan publik berpedoman pada SPAP (di Amerika GAAS). Agar pemeriksaan dapat dilakukan secara kritis, pemeriksaan harus dipimpin oleh seorang yang bergelar akuntan dan mempunyai ijin praktek sebagai akuntan publik dari Menteri Keuangan. Pelaksana pemeriksaan harus berpendidikan, berpengalaman dan berkeahlian di bidang akuntansi, perpajakan, sistem akuntansi dan pemeriksaan akuntansi.

Agar pemeriksaan dapat dilakukan secara sistematis, akuntan publik harus merencanakan pemeriksaannya sebelum proses pemeriksaan dimulai dengan membuat audit plan yang memuat kapan pemeriksaan dimulai, berapa lama, kapan laporan harus selesai, berapa orang staf yang ditugaskan, masalah-masalah yang diperkirakan akan dihadapi di bidang auditing, akuntansi dan perpajakan.

3. Pemeriksaan dilakukan oleh pihak yang independen, yaitu akuntan publik. Independen berarti tidak mempunyai kepentingan tertentu di perusahaan tersebut (misalkan auditor sebagai pemegang saham, direksi) atau mempunyai hubungan khusus (misalkan auditor menjadi keluarga dari pemegang saham, direksi).

Akuntan publik harus independen karena sebagai orang kepercayaan masyarakat, harus bekerja secara objektif, tidak memihak dan melaporkan apa adanya.

4. Tujuan pemeriksaan akuntan adalah untuk dapat memberikan pendapat mengenai kewajaran laporan keuangan yang diperiksa.

Laporan keuangan yang wajar adalah yang disusun berdasarkan PABU (di Indonesia: SAK, di Amerika: GAAP), diterapkan secara konsisten, dan tidak mengandung kesalahan yang material.

Akuntan publik tidak menyatakan bahwa laporan keuangan tersebut benar, karena pemeriksaannya dilakukan secara sampling, sehingga mungkin saja terdapat kesalahan dalam laporan keuangan tetapi jumlahnya tidak material sehingga tidak mempengaruhi kewajaran laporan keuangan secara keseluruhan.

\section{Standart Audit}

Dalam pelaksanaan audit, Akuntan publik menggunakan suatu ukuran standar sebagai pedoman umum yang diharapkan dengan menggunakan pedoman tersebut tujuan umum audit dapat tercapai. Menurut Mulyadi (2002:14) "Standar auditing adalah suatu ukuran pelaksanaan tindakan yang merupakan pedoman umum bagi auditor dalam melaksanakan audit”. Sedangkan menurut Sukrisno Agoes (2000:18) menyatakanpengertian standar auditing sebagai berikut : 
"Standar auditing adalah sebagai suatu yang berkenaan dengan kriteria atau ukuran mutu pelaksanaan serta dikaitkan dengan tujuan yanghendak dicapai dengan menggunakan prosedur yang bersangkutan, jadidalam hal ini standar auditing mencakup mutu profesionalisme ( ProfesionalQualities) auditor independen dan pertimbangan (judgement) yangdigunakan dalam pelaksanaan audit dan penyusunan laporan auditor".

Selanjutnya, Stamp dan Moonitz (1988: 1) beranggapan auditing memiliki manifestasi tertinggi dari seni (dan ilmu pengetahuan) akunting keuangan. Kompetennya akunting keuangan suatu entitas yang ditetapkan oleh profesi akuntansi, kredibilitasnya masih diragukan user luar. Informasi yang disampaikan entitas atas laporan keuangannya memerlukan kredibilitas diantaranya menggunakan pihak independen dengan menggunakan audit.

PSA (Penyusunan Audit Report) merupakan penjabaran lebih lanjut dari masingmasing standar yang tercantum di dalam standar auditing. PSA berisi ketentuan-ketentuan dan pedoman utama yang harus diikuti oleh Akuntan Publik dalam melaksanakan penugasan audit. Kepatuhan terhadap PSA yang diterbitkan oleh IAPI ini bersifat wajib bagi seluruh anggota IAPI. Termasuk di dalam PSA adalah Interpretasi Pernyataan Standar Auditng (IPSA), yang merupakan interpretasi resmi yang dikeluarkan oleh IAPI terhadap ketentuan-ketentuan yang diterbitkan oleh IAPI dalam PSA. Dengan demikian, IPSA memberikan jawaban atas pernyataan atau keraguan dalam penafsiran ketentuan-ketentuan yang dimuat dalam PSA sehingga merupakan perlausan lebih lanjut berbagai ketentuan dalam PSA.

\section{SAK ETAP}

Standar Akuntansi Keuangan untuk Entitas Tanpa Akuntabilitas Publik (SAK-ETAP) atau The Indonesian Accounting Standards for Non-Publicly-Accountable Entities, merupakan standar akuntansi keuangan yang diterbitkan oleh IAI dan telah disahkan oleh Dewan tandar Akuntansi Keuangan Ikatan Akuntan Indonesia (DSAK IAI) yang ditujukan untuk perusahaan kecil dan menengah (UKM). Alasan IAI menerbitkan standar ini adalah untuk mempermudah perusahaan kecil dan menengah (UKM) (yang jumlahnya hampir dari $90 \%$ dari total perusahaan di Indonesia) dalam menyusun laporan keuangan mereka. Dimana jikalau standar ini tidak diterbitkan mereka juga harus mengikuti SAK baru (yang merupakan SAK yang sedang dalam tahap pengadopsian IFRS - konvergensi penuh tahun 2012) untuk menyusun laporan keuangan mereka. SAK berbasis IFRS ini relatif lebih kompleks dan sangat mahal bagi perusahaan kecil dan menengah untuk menerapkannya. 
SAK-ETAP mengadopsi sebagian IFRS (International Financial Reporting Standards) untuk usaha kecil-menengah (IFRS for Small-Medium-sized Entities/SMEs).

Terdapat dua kriteria yang menentukan apakah suatu entitas tergolong entitas tanpa akuntabilitas publik (ETAP) yaitu:

\section{Tidak memiliki akuntabilitas publik yang signifikan; dan}

Suatu entitas dikatakan memiliki akuntabilitas yang signifikan jika:

a. entitas telah mengajukan pernyataan pendaftaran atau entitas dalam proses pengajuan pernyataan pendaftaran pada otoritas pasar modal (BAPEPAM-LK) atau regulator lain untuk tujuan penerbitan efek di pasar modal. Oleh sebab itu Bapepam sendiri telah mengeluarkan surat edaran (SE) Bapepam-LK No. SE06/BL/2010 tentang larangan penggunaan SAK ETAP bagi lembaga pasar modal, termasuk emiten, perusahaan publik, manajer investasi, sekuritas, asuransi, reksa dana, dan kontrak investasi kolektif.

b. entitas menguasai aset dalam kapasitas sebaga fidusia untuk sekelompok besar masyarakat, seperti bank, entitas asuransi, pialang dan/atau pedagang efek, dana pensiun, reksa dana, dan bank investasi.

2. Tidak menerbitkan laporan keuangan untuk tujuan umum (general purpose financial statements) bagi pengguna eksternal. Contoh pengguna eksternal adalah pemilik yang tidak terlibat langsung dalam pengelolaan usaha, kreditur dan lembaga pemeringkat kredit.

\section{PEMBAHASAN}

\section{Perbedaan PSAK dan SAK ETAP}

Secara umum, SAK ETAP mengemas ketentuan pelaporan yang lebih sederhana dibandingkan dengan PSAK. Sesuai dengan ruang lingkup SAK-ETAP, standar ini dimaksudkan untuk digunakan oleh entitas tanpa akuntabilitas publik, yaitu entitas yang tidak memiliki akuntabilitas publik signifikan dan tidak menerbitkan laporan keuangan untuk tujuan umum (general purpose financial statement) bagi pengguna eksternal.

Entitas memiliki akuntabilitas publik dikatakan signifikan jika entitas telah mengajukan pernyataan, pendaftaran, atau dalam proses pengajuan, pernyataan pendaftaran, pada otoritas pasar modal atau regulator lain untuk tujuan penerbitan efek di pasar modal; atau efek di pasar modal; atau entitas menguasai aset dalam kapasitas sebagai fidusia untuk sekelompok besar masyarakat, seperti bank, entitas asuransi, pialang adan atau pedagang efek, dana pensiun, reksa dana dan bank investasi. Entitas yang memiliki akuntabilitas publik signifikan dapat menggunakan SAK-ETAP jika pihak regulator mengizinkan 
penggunaan standar tersebut. Ijin ini muncul karena alasan biaya yang tinggi dan mekanisme yang telalu rumit ketika menerapkan PSAK.

Tentunya terdapat alasan mengapa IAI mengeluarkan standar baru bagi perusahaan kecil menengah, diantaranya ditemui kendala-kenala sebagai berikut :

a. PSAK- IFRS sulit diterapkan bagi perusahaan menengah kecil mengingat penentuan fair value memerlukan biaya yang tidak murah

b. PSAK-IFRS lebih rumit untuk diimplementasikan, karena terlalu sering berganti peraturan seperti kasus kasus PSAK 50 dan PSAK 55, meskipun sudah disahkan tahun 2006 namun implementasinya tertunda bahkan 2010 sudah keluar PSAK 50 (revisi)

c. PSAK-IFRS menggunakan principle based sehingga membutuhkan banyak professional judgement

d. PSAK - IFRS perlu dokumentasi dan aplikasi teknologi informasi yang kuat.

\section{Standar audit berdasarkan pada SAK-ETAP}

Penerapan SAK ETAP, dengan pengungkapan tambahan jika diperlukan, menghasilkan laporan keuangan yang wajar atas posisi keuangan, kinerja keuangan, dan arus kas entitas. Pengungkapan tambahan diperlukan ketika kepatuhan atas persyaratan tertentu dalam SAK ETAP tidak memadai bagi pemakai untuk memahami pengaruh dari transaksi tertentu, peristiwa dan kondisi lain atas posisi keuangan dan kinerja keuangan entitas.

\section{Kepatuhan Terhadap SAK ETAP}

Entitas yang laporan keuangannya mematuhi SAK ETAP harus membuat suatu pernyataan eksplisit dan secara penuh (explicit and unreserved statement) atas kepatuhan tersebut dalam catatan atas laporan keuangan. Laporan keuangan tidak boleh menyatakan mematuhi SAK ETAP kecuali jika mematuhi semua persyaratan dalam SAK ETAP.

\section{Kelangsungan Usaha}

Pada saat menyusun laporan keuangan, manajemen entitas yang menggunakan SAK ETAP membuat penilaian atas kemampuan entitas melanjutkan kelangsungan usaha. Entitas mempunyai kelangsungan usaha kecuali jika manajemen bermaksud melikuidasi entitas tersebut atau menghentikan operasi, atau tidak mempunyai alternatif realistis kecuali melakukan hal-hal tersebut. Dalam membuat penilaian kelangsungan usaha, jika manajemen menyadari terdapat ketidakpastian yang material terkait dengan peristiwa atau kondisi yang mengakibatkan keraguan signifikan terhadap kemampuan entitas untuk melanjutkan usaha, maka entitas harus mengungkapkan ketidakpastian tersebut. 


\section{NERACA}

\section{Informasi yang Disajikan Dalam Neraca}

Neraca minimal mencakup pos-pos berikut: (a) kas dan setara kas, (b) piutang usaha dan piutang lainnya; (c) persediaan; (d) properti investasi; (e) aset tetap; (f) aset tidak berwujud; (g) utang usaha dan utang lainnya; (h) aset dan kewajiban pajak; (i) kewajiban diestimasi; (j) ekuitas.

Entitas menyajikan pos, judul dan sub jumlah lainnya dalam neraca jika penyajian seperti itu relevan dalam rangka pemahaman terhadap posisi keuangan entitas. SAK ETAP tidak menentukan format atau urutan terhadap pos-pos yang disajikan.

\section{Klasifikasi Aset dan Kewajiban}

Entitas harus menyajikan aset lancar dan aset tidak lancar, kewajiban jangka pendek dan kewajiban jangka panjang, sebagai suatu klasifikasi yang terpisah dalam neraca sesuai paragraf 4.6-4.9, kecuali jika penyajian berdasarkan likuiditas memberikan informasi yang andal dan lebih relevan. Jika pengecualian tersebut diterapkan, maka semua aset dan kewajiban harus disajikan berdasarkan likuiditasnya.

\section{Aset Lancar}

Entitas mengklasifikasikan aset sebagai aset lancar jika: (a) diperkirakan akan direalisasi atau dimiliki untuk dijual atau digunakan, dalam jangka waktu siklus operasi normal entitas; (b) dimiliki untuk diperdagangkan; (c) diharapkan akan direalisasi dalam jangka waktu 12 bulan setelah akhir periode pelaporan; (d) berupa kas atau setara kas, kecuali jika dibatasi penggunaannya dari pertukaran atau digunakan untuk menyelesaikan kewajiban setidaknya 12 bulan setelah akhir periode pelaporan.

Entitas mengklasifikasikan semua aset lainnya sebagai tidak lancar. Jika siklus operasi normal entitas tidak dapat diidentifikasi dengan jelas, maka siklus operasi diasumsikan 12 bulan.

\section{Kewajiban Jangka Pendek}

Entitas harus mengklasifikasikan semua kewajiban lainnya sebagai kewajiban jangka panjang. Klasifikasi kewajiban sebagai kewajiban jangka pendek jika: (a) diperkirakan akan diselesaikan dalam jangka waktu siklus normal operasi entitas; (b) dimiliki untuk diperdagangkan; (c) kewajiban akan diselesaikan dalam jangka waktu 12 bulan setelah akhir periode pelaporan; (d) entitas tidak memiliki hak tanpa syarat untuk menunda penyelesaian kewajiban setidaknya 12 bulan setelah akhir periode pelaporan

\section{Urutan dan Format Pos dalam Neraca}

SAK ETAP tidak menentukan format atau urutan terhadap pos-pos yang akan disajikan. Paragraf 4.2 hanya menyediakan daftar pos-pos yang berbeda baik sifat atau fungsinya untuk menjamin penyajian yang terpisah dalam neraca. Sebagai tambahan: 
a) pos yang terpisah akan dibentuk jika ukuran, sifat, atau fungsi dari pos atau agregasi terhadap pos-pos yang serupa membuat penyajian terpisah menjadi relevan untuk memahami posisi keuangan entitas; dan

b) uraian yang digunakan dan urutan pos-pos atau agregasi terhadap pos-pos yang sejenis mungkin diubah sesuai dengan sifat entitas dan transaksinya, untuk menyediakan informasi yang relevan dalam rangka memahami posisi keuangan entitas.

Pertimbangan atas pos-pos tambahan yang disajikan secara terpisah berdasarkan pada penilaian: (a) sifat dan likuiditas aset; (b) fungsi aset dalam entitas; dan (c) jumlah, sifat dan waktu kewajiban.

\section{LABA RUGI}

\section{Informasi yang Disajikan di Laporan Laba Rugi}

Laporan laba rugi minimal mencakup pos-pos sebagai berikut: (a) pendapatan; (b) beban keuangan; (c) bagian laba atau rugi dari investasi yang menggunakan metode ekuitas; (d) beban pajak; (e) laba atau rugi neto.

Entitas harus menyajikan pos, judul dan sub jumlah lainnya pada laporan laba rugi jika penyajian tersebut relevan untuk memahami kinerja keuangan entitas. Entitas tidak boleh menyajikan atau mengungkapkan pos pendapatan dan beban sebagai "pos luar biasa", baik dalam laporan laba rugi maupun dalam catatan atas laporan keuangan.

\section{Analisis Beban}

Entitas menyajikan suatu analisis beban dalam suatu klasifikasi berdasarkan sifat atau fungsi beban dalam entitas, mana yang memberikan informasi yang lebih andal dan relevan. Analisis Menggunakan Sifat Beban

Berdasarkan metode ini, beban dikumpulkan dalam laporan laba rugi berdasarkan sifatnya (contoh, penyusutan, pembelian bahan baku, biaya transportasi, imbalan kerja dan biaya iklan), dan tidak dialokasikan kembali antara berbagai fungsi dalam entitas.

Misalnya:

Pendapatan

$\mathrm{XXX}$

Pendapatan operasi lain

$X X X$

Perubahan persediaan barang jadi

dan barang dalam proses

$\mathrm{XXX}$

Bahan baku yang digunakan

$x x x$

Beban pegawai

$\mathrm{XXX}$

Beban penyusutan dan amortisasi

$\mathrm{XXX}$

Beban operasi lainnya

$\underline{X X X}$

Jumlah beban operasi 


\section{Analisis Menggunakan Fungsi Beban}

Berdasarkan metode ini, beban dikumpulkan sesuai fungsinya sebagai bagian dari biaya penjualan atau, sebagai contoh, biaya aktivitas distribusi atau aktivitas administrasi.

Sekurang-kurangnya, entitas harus mengungkapkan biaya penjualannya sesuai metode ini terpisah dari beban lainnya.

Misalnya:

Pendapatan

$\mathrm{X}$

Beban pokok penjualan

$(\mathrm{x})$

Laba bruto

$\mathrm{x}$

Pendapatan operasi lainnya

$\mathrm{X}$

Beban pemasaran

$(\mathrm{x})$

Beban umum dan administrasi

$(\mathrm{x})$

Beban operasi lain

$(x)$

Laba operasi

$\mathrm{x}$

Entitas dianjurkan untuk menyajikan analisis diatas pada laporan laba rugi. Entitas yang mengklasifikasikan beban berdasarkan fungsi mengungkapkan informasi tambahan berdasarkan sifat beban, termasuk penyusutan dan beban amortisasi dan beban imbalan kerja.

\section{LAPORAN PERUBAHAN EKUITAS DAN LAPORAN LABA RUGI DAN SALDO LABA}

\section{Laporan Perubahan Ekuitas}

Laporan perubahan ekuitas menyajikan laba atau rugi entitas untuk suatu periode, pos pendapatan dan beban yang diakui secara langsung dalam ekuitas untuk periode tersebut, pengaruh perubahan kebijakan akuntansi dan koreksi kesalahan yang diakui dalam periode tersebut, dan (tergantung pada format laporan perubahan ekuitas yang dipilih oleh entitas) jumlah investasi oleh, dan dividen dan distribusi lain ke, pemilik ekuitas selama periode tersebut.

\section{EKUITAS}

\section{Informasi yang Disajikan di Laporan Perubahan Ekuitas}

Entitas menyajikan laporan perubahan ekuitas yang menunjukkan:

a. laba atau rugi untuk periode;

b. pendapatan dan beban yang diakui langsung dalam ekuitas; 
c. untuk setiap komponen ekuitas, pengaruh perubahan kebijakan akuntansi dan koreksi kesalahan yang diakui sesuai Bab 9 Kebijakan Akuntansi, Estimasi, dan Kesalahan;

d. untuk setiap komponen ekuitas, suatu rekonsiliasi antarajumlah tercatat awal dan akhir periode, diungkapkan secara terpisah perubahan yang berasal dari:

(i) laba atau rugi;

(ii) pendapatan dan beban yang diakui langsung dalam ekuitas;

(iii) jumlah investasi, dividen dan distribusi lainnya ke pemilik ekuitas, yang menunjukkan secara terpisah modal saham, transaksi saham treasuri, dan dividen serta distribusi lainnya ke pemilik ekuitas, dan perubahan kepemilikan dalam entitas anak yang tidak mengakibatkan kehilangan pengendalian.

\section{LAPORAN LABA RUGI DAN SALDO LABA}

Laporan laba rugi dan saldo laba menyajikan laba atau rugi entitas dan perubahan saldo laba untuk suatu periode pelaporan. Paragraf 3.13 mengijinkan entitas untuk menyajikan laporan laba rugi dan saldo laba menggantikan laporan laba rugi dan laporan perubahan ekuitas jika perubahan pada ekuitashanya berasal dari laba atau rugi, pembayaran dividen, koreksi kesalahan periode lalu, dan perubahan kebijakan akuntansi.

\section{Informasi yang Disajikan di Laporan Laba Rugi dan Saldo Laba}

Entitas menyajikan di laporan laba rugi dan saldo laba pos-pos berikut sebagai tambahan atas informasi yang disyaratkan dalam Bab 5 Laporan Laba Rugi:

a. saldo laba pada awal periode pelaporan;

b. dividen yang diumumkan dan dibayarkan atau terutang selama periode;

c. penyajian kembali saldo laba setelah koreksi kesalahan periode lalu;

d. penyajian kembali saldo laba setelah perubahan kebijakan akuntansi; dan

e. saldo laba pada akhir periode pelaporan.

\section{LAPORAN ARUS KAS}

Bab ini mengatur informasi yang disajikan dalam laporan arus kas dan bagaimana penyajiannya. Laporan arus kas menyajikan informasi perubahan historis atas kas dan setara kas entitas, yang menunjukkan secara terpisah perubahan yang terjadi selama satu periode dari aktivitas operasi, investasi, dan pendanaan.

\section{Setara Kas}

Setara kas adalah investasi jangka pendek dan sangat likuid yang dimiliki untuk memenuhi komitmen kas jangka pendek, bukan untuk tujuan investasi atau lainnya. Oleh karena itu, investasi umumnya diklasifikasikan sebagai setara kas hanya jika akan segera jatuh tempo dalam waktu tiga bulan atau kurang sejak tanggal perolehan. Cerukan bank 
pada umumnya termasuk aktivitas pendanaan sejenis dengan pinjaman. Namun, jika cerukan bank dapat ditarik sewaktu-waktu dan merupakan bagian yang tak terpisahkan dari pengelolaan kas entitas, maka cerukan tersebut termasuk komponen kas dan setara kas.

\section{Informasi yang Disajikan dalam Laporan Arus Kas}

Entitas menyajikan laporan arus kas yang melaporkan arus kas untuk suatu periode dan mengklasifikasikan menurut aktivitas operasi, aktivitas investasi, dan aktivitas pendanaan.

\section{Aktivitas Operasi}

Arus kas dari aktivitas operasi terutama diperoleh dari aktivitas penghasil utama pendapatan entitas. Oleh karena itu, arus kas tersebut pada umumnya berasal dari transaksi dan peristiwa dan kondisi lain yang mempengaruhi penetapan laba atau rugi. Contoh arus kas dari aktivitas operasi adalah:

a. penerimaan kas dari penjualan barang dan jasa;

b. penerimaan kas dari royalti, fees, komisi dan pendapatan lain;

c. pembayaran kas kepada pemasok barang dan jasa;

d. pembayaran kas kepada dan atas nama karyawan;

e. pembayaran kas atau restitusi pajak penghasilan kecuali jika dapat diidentifikasikan secara khusus sebagai bagian dari aktivitas pendanaan dan investasi;

f. penerimaan dan pembayaran kas dari investasi, pinjaman, dan kontrak lainnya yang dimiliki untuk tujuan perdagangan, yang sejenis dengan persediaan yang dimaksudkan untuk dijual kembali.

Beberapa transaksi, seperti penjualan peralatan pabrik, dapat menimbulkan keuntungan atau kerugian yang dimasukkan dalam perhitungan laba atau rugi. Tetapi, arus kas yang menyangkut transaksi tersebut merupakan arus kas dari aktivitas investasi.

\section{Aktivitas Investasi}

Arus kas dari aktivitas investasi mencerminkan pengeluaran kas sehubungan dengan sumber daya yang bertujuan untuk menghasilkan pendapatan dan arus kas masa depan. Contoh arus kas yang berasal dari aktivitas investasi adalah:

a. pembayaran kas untuk memperoleh aset tetap (termasuk aset tetap yang dibangun sendiri), aset tidak berwujud dan aset jangka panjang lainnya;

b. penerimaan kas dari penjualan aset tetap, aset tidak berwujud, dan aset jangka panjang lainnya;

c. pembayaran kas untuk perolehan efek ekuitas atau efek utang entitas lain dan bunga dalam joint venture (selain pembayaran untuk efek yang diklasifikasikan sebagai kas atau setara kas atau dimiliki untuk diperdagangkan); 
d. penerimaan kas dari penjualan efek ekuitas atau efek utang dari entitas lain dan bunga dari joint venture (selain penerimaan dari efek yang diklasifikasikan sebagai setara kas atau dimiliki untuk diperdagangkan);

e. uang muka dan pinjaman yang diberikan kepada pihak lain;

f. penerimaan kas dari pembayaran kembali uang muka dan pinjaman yang diberikan kepada pihak lain;

\section{Aktivitas Pendanaan}

Contoh arus kas yang berasal dari aktivitas pendanaan adalah:

a. penerimaan kas dari penerbitan saham atau efek ekuitas lain;

b. pembayaran kas kepada para pemegang saham untuk menarik atau menebus saham entitas;

c. penerimaan kas dari penerbitan pinjaman, wesel, dan pinjaman jangka pendek atau jangka panjang lainnya;

d. pelunasan pinjaman;

e. pembayaran kas oleh lessee untuk mengurangi saldo kewajiban yang berkaitan dengan sewa pembiayaan.

\section{Pelaporan Arus Kas dari Aktivitas Operasi}

Entitas melaporkan arus kas dari aktivitas operasi dengan menggunakan metode tidak langsung. Dalam metode ini laba atau rugi neto disesuaikan dengan mengoreksi dampak dari transaksi non kas, penangguhan atau akrual dari penerimaan atau pembayaran kas untuk operasi di masa lalu dan masa depan, dan unsur penghasilan atau beban yang berkaitan dengan arus kas investasi atau pendanaan.

Dalam metode tidak langsung, arus kas neto dari aktivitas operasi ditentukan dengan menyesuaikan laba atau rugi dari dampak dari:

a. perubahan persediaan dan piutang usaha serta utang usaha selama periode berjalan;

b. pos non kas seperti penyusutan, penyisihan, dan keuntungan dan kerugian valuta asing yang belum direalisasi; dan

c. semua pos lain yang berkaitan dengan arus kas investasi atau pendanaan.

\section{Pelaporan Arus Kas dari Aktivitas Investasi dan Pendanaan}

Entitas melaporkan secara terpisah kelompok utama penerimaan kas bruto dan pengeluaran kas bruto yang berasal dari aktivitas investasi dan pendanaan. Jumlah agregat arus kas yang berasal dari akuisisi dan pelepasan entitas anak atau unit usaha lain disajikan secara terpisah dan diklasifikasikan sebagai arus kas dari aktivitas operasi. 


\section{Bunga dan Dividen}

Entitas mengungkapkan secara terpisah arus kas dari bunga dan dividen yang diterima dan dibayarkan. Entitas mengklasifikasikan arus kas secara konsisten antar periode sebagai aktivitas operasi, investasi, atau pendanaan.

Entitas mengklasifikasikan bunga yang dibayarkan dan bunga dan dividen yang diterima sebagai arus kas operasi karena termasuk laba atau rugi. Sebagai alternatif, bunga yang dibayarkan dan bunga dan dividen yang diterima dapat diklasifikasikan sebagai arus kas pendanaan dan arus kas investasi, karena merupakan biaya perolehan sumber daya keuangan atau hasil investasi.

Dividen yang dibayarkan dapat diklasifikasikan sebagai arus kas pendanaan karena merupakan biaya perolehan sumber daya keuangan. Sebagai alternatif, dividen yang dibayarkan dapat diklasifikasikan sebagai komponen arus kas dari aktivitas operasi karena dividen dibayarkan dari arus kas operasi.

\section{Pajak Penghasilan}

Entitas mengungkapkan secara terpisah arus kas yang berkaitan dengan pajak penghasilan dan mengklasifikasikannya sebagai arus kas aktivitas operasi, kecuali jika secara spesifik dapat diidentifikasikan dengan aktivitas pendanaan dan investasi. Jika arus kas pajak dialokasikan pada lebih dari satu jenis aktivitas, maka jumlah keseluruhan pajak yang dibayar harus diungkapkan.

\section{Transaksi Nonkas}

Entitas mengeluarkan dari laporan arus kas, transaksi investasi dan pendanaan yang tidak memerlukan penggunaan kas atau setara kas. Entitas mengungkapkan transaksi tersebut dalam laporan keuangan sehingga memberikan semua informasi yang relevan mengenai aktivitas investasi dan pendanaan tersebut.

Banyak aktivitas investasi dan pendanaan yang tidak mempunyai dampak langsung terhadap arus kas saat ini meskipun mempengaruhi struktur aset dan modal entitas. Tidak dimasukkannya transaksi non kas dalam laporan arus kas adalah konsisten dengan tujuan laporan arus kas sebab transaksi tersebut tidak mempengaruhi arus kas dalam periode berjalan.

Contoh transaksi non kas adalah:

a. perolehan aset secara kredit atau melalui sewa pembiayaan.

b. akuisisi suatu entitas melalui emisi saham.

c. konversi utang menjadi modal.

\section{Komponen Kas dan Setara Kas}


Entitas mengungkapkan komponen kas dan setara kas dan menyajikan rekonsiliasi jumlah yang dilaporkan dalam laporan arus kas dengan pos yang sama yang disajikan dalam neraca.

\section{Pengungkapan Lain}

Entitas mengungkapkan, bersama dengan pendapat manajemen, jumlah kas dan setara kas yang signifikan yang dimiliki entitas, namun tidak dapat digunakan oleh entitas. Hal ini karena adanya pembatasan lalu lintas devisa atau pembatasan hukum

\section{Penyajian}

Seperti yang telah dijelaskan pada bab sebelumnya tenang asersi manajemen, maka dalam implementasi antara PSAK dan ETAP terdapat perbedaan pada asersi pengungkapan/penyajiannya. Untuk asersi lainnya seperti keberadaan, kelengkapan, hak dna kewajiban serta penilaian dan alokasi pada dasarnya antara PSAK dan ETAP memiliki kesamaan konsep. Sedangkan pada asersi penyajian, seperti yang telah dipaparkan sebelumnya bahwa SAK-ETAP memiliki bentuk yang lebih sederhana dibandingkan dengan PSAK, oleh karena itu pasti terdapat perbedaan penyajian di antara keduanya.

Perbedaan penyajian tersebut dapat dilihat pada tabel di bawah ini:

\section{SAK UMUM vs SAK ETAP}

\begin{tabular}{|c|c|c|}
\hline & SAK UMUM & SAK ETAP \\
\hline $\begin{array}{l}\text { Penyajian Laporan } \\
\text { Keuangan }\end{array}$ & $\begin{array}{l}\text { Dengan adanya ED PSAK } 1 \\
\text { di masa depan penyajian } \\
\text { laporan keuangan mengikuti } \\
\text { IFRS dengan perubahan } \\
\text { antara lain, } \\
\text { - Tidak ada lagi pos luar } \\
\text { biasa pada neraca } \\
\text { - } \quad \text { Laba Rugi komprehensive } \\
\text { - Cash flow metode } \\
\text { langsung (dianjurkan), } \\
\text { dan tidak langsung. }\end{array}$ & $\begin{array}{c}\text { Minimum pos yang harus } \\
\text { ada di neraca lebih sedikit. } \\
\text { - } \\
\text { Silent terhadap pos } \\
\text { - } \quad \text { Lapar biasa } \\
\text { (tanpa harus } \\
\text { menyajikan laba rugi } \\
\text { komprehensive) } \\
\text { - } \quad \text { Cash flow dengan } \\
\text { metode tidak } \\
\text { langsung }\end{array}$ \\
\hline $\begin{array}{l}\text { Aset Tetap dan Properti } \\
\text { Investasi }\end{array}$ & $\begin{array}{l}\text { 1. Memberikan pilihan } \\
\text { metode biaya atau } \\
\text { revaluasi untuk aset tetap. } \\
\text { 2. Metode Fair value untuk } \\
\text { properti investasi. }\end{array}$ & $\begin{array}{l}\text { Aset tetap, properti investasi } \\
\text { menggunakan metode biaya } \\
\text { kecuali ada ketentuan } \\
\text { pemerintah yang } \\
\text { mengharuskan model } \\
\text { revaluasi diterapkan. }\end{array}$ \\
\hline Aset Tidak Berwujud & $\begin{array}{l}\text { Saat ini aset tidak } \\
\text { berwujud diamortisasi } \\
\text { selama 20th. } \\
\text { ED PSAK } 19 \text { (Terbit } \\
\text { 2011) } \\
\text { - Aset tidak berwujud } \\
\text { dengan masa manfaat tak }\end{array}$ & $\begin{array}{l}\text { - } \text { Aset tidak berwujud } \\
\text { diamortisasi selama 10th. } \\
\text { - } \text { Pengukuran } \\
\text { menggunakan metode } \\
\text { biaya. }\end{array}$ \\
\hline
\end{tabular}




\begin{tabular}{|c|c|c|}
\hline & terbatas, tidak diamortisasi. & \\
\hline Instrumen Keuangan & $\begin{array}{l}\text { - Ruang lingkup: aset dan } \\
\text { kewajiban keuangan, } \\
\text { - Diklasifikasikan pada nilai } \\
\text { wajar melalui laporan laba } \\
\text { rugi, dimiliki hingga jatuh } \\
\text { tempo, tersedia untuk } \\
\text { dijual, pinjaman dan } \\
\text { pinjaman yang diberikan. } \\
\text { - Impayment menggunakan } \\
\text { incurred loss concept. } \\
\text { - Derecognition } \\
\text { - Hedging dan derivatif. }\end{array}$ & $\begin{array}{l}\text { - } \text { Ruang lingkup; investasi } \\
\text { pada efek tertentu } \\
\text { Klasifikasi trading, held } \\
\text { to maturity, dan available } \\
\text { for sale. Hal tsb mengacu } \\
\text { pada PSAK no } 50 \text { (1998). } \\
\text { Jauh lebih sederhana } \\
\text { dibanding ketentuan PSAK } \\
50 \text { dan PSAK } 55 \text { (revisi } \\
\text { 2006) }\end{array}$ \\
\hline Persediaan & $\begin{array}{l}\text { LIFO tidak lagi diijinkan } \\
\text { (PSAK } 14 \text { revisi 2008) }\end{array}$ & $\begin{array}{l}\text { LIFO tidak diijinkan } \\
\text { Ketentuan lainnya sama } \\
\text { dengan PSAK }\end{array}$ \\
\hline Penurunan nilai Aset & $\begin{array}{l}\text { - Ruang lingkup kecuali; } \\
\text { persediaan, aset yang } \\
\text { timbul dari kontrak } \\
\text { konstruksi, aset pajak } \\
\text { tangguhan, aset yang } \\
\text { timbul dari manfaat } \\
\text { pensiun. } \\
\text { - Penurunan nilai non } \\
\text { persediaan. } \\
\text { - Penurunan nilai unit } \\
\text { penghasil kas dan } \\
\text { goodwill. }\end{array}$ & $\begin{array}{l}\text { - } \text { Ruang lingkup yang } \\
\text { meliputi semua jenis aset } \\
\text { kecuali aset yang timbul } \\
\text { dari manfaat pensiun. } \\
\text { - } \quad \text { Tidak mengatur } \\
\text { penurunan nilai goodwill. } \\
\text { - Ada tambahan } \\
\text { penurunan nilai untuk } \\
\text { pinjaman yang diberikan } \\
\text { dan piutang yang } \\
\text { menggunakan PSAK } 31 .\end{array}$ \\
\hline $\begin{array}{l}\text { Laporan Keuangan } \\
\text { Konsolidasian }\end{array}$ & $\begin{array}{l}\text { Diatur dalam PSAK } 4 \\
\text { Menggunakan metode } \\
\text { ekuitas (entitas asosiasi) dan } \\
\text { metode konsolidasi penuh } \\
\text { untuk entitas anak. }\end{array}$ & $\begin{array}{l}\text { Tidak Diatur } \\
\text { Bila memiliki investasi atas } \\
\text { asosiasi maupun subsidiary } \\
\text { menggunakan metode } \\
\text { ekuitas ( on line } \\
\text { cosolidation). }\end{array}$ \\
\hline Sewa & $\begin{array}{l}\text { - Mengatur perjanjian yang } \\
\text { mengandung sewa. } \\
\text { - Klasifikasi berifat principle } \\
\text { based. } \\
\text { - Laporan keuangan lessee } \\
\text { dan lessor }\end{array}$ & $\begin{array}{l}\text { Tidak mengatir perjanjian } \\
\text { yang mengandung sewa ( } \\
\text { psak 8) } \\
\text { Klasifikasi sewa; } \\
\text { kombinasi IFRS for SMEs } \\
\text { dan SFAS } 13 \text { (rule based) } \\
\text { - Laporan keungan lessee } \\
\text { dan lessor menggunakan } \\
\text { PSAK } 30 \text { (1990): } \\
\text { Akuntansi Sewa }\end{array}$ \\
\hline Biaya Pinjaman & $\begin{array}{l}\text { Komponen biaya pinjaman } \\
\text { Pengakuan dan kapitalisasi } \\
\text { biaya pinjaman }\end{array}$ & $\begin{array}{l}\text { Biaya pinjaman langsung } \\
\text { dibebankan. }\end{array}$ \\
\hline Imbalan Kerja & $\begin{array}{l}\text { Menjelaskan: } \\
\text { - Imbalan kerja jangka } \\
\text { pendek } \\
\text { - Imbalan pasca kerja, untuk }\end{array}$ & $\begin{array}{l}\text { Tidak termasuk imbalan } \\
\text { berbasis ekuitas } \\
\text { Untuk mafaat pasti } \\
\text { mengunakan PUC dan jika }\end{array}$ \\
\hline
\end{tabular}




\begin{tabular}{|l|l|l|} 
& manfaat pasti & tidak bisa, menggunakan \\
& menggunakan PUC (Prject & metode yang \\
Unit Credit) & disederhanakan. \\
& - Imbalan jangka panjang & \\
& lainnya & \\
& - Pesangon pemutusan & \\
& kerja & \\
& - Imbalan berbasis ekuitas & \\
\hline Pajak Penghasilan & - Menggunakan deffered tax & - Menggunakan tax \\
& Concept & payable concept. \\
& - Penagkuan dan & Tidak ada pengakuan \\
& pengukuran pajak kini & dan pengukuran pajak \\
& - Pengakuan dan & tangguhan. \\
& pengukuran pajak & \\
& tangguhan & \\
\hline
\end{tabular}

Ketika sebuah entitas menggunakan SAK ETAP sebagai dasar penyusunan laporan keuangan, maka tentunya standar auditing juga harus mengikuti aturan yang tertera di SAK ETAP. Seperti yang telah dijelaskan di atas, bahwa SAK ETAP lebih sederhana dibandingakn dengan PSAK, maka tentunya standar auditing akan lebih sederhana. Secara teknis, perbedaan antara PSAK dan SAK ETAP terlihat dari tabel berikut ini:

\begin{tabular}{|c|c|c|c|}
\hline No & Elemen & PSAK & SAK ETAP \\
\hline 1 & $\begin{array}{l}\text { Penyajian Laporan } \\
\text { Keuangan }\end{array}$ & $\begin{array}{l}\text { - } \quad \text { Laporan posisi keuangan } \\
\text { - } \text { Informasi yang disajikan } \\
\text { dalam laporan posisi } \\
\text { keuangan } \\
\text { - } \quad \text { Pembedaan asset lancar dan } \\
\text { tidak lancar dan laibilitas } \\
\text { jangka pendek dan jangka } \\
\text { panjang } \\
\text { - } \quad \text { Aset lancar } \\
\text { - } \quad \text { Inforilitas jangka pendek } \\
\quad \text { dalam laporan posisi } \\
\quad \text { keuangan atau catatan atas } \\
\text { laporan keuangan } \\
\text { (Perubahan istilah di ED PSAK } \\
\text { 1: Neraca menjadi Laporan Posisi } \\
\text { Keuangan, Kewajiban (liability) } \\
\text { menjadi laibilitas) }\end{array}$ & $\begin{array}{l}\text { Sama dengan PSAK, kecuali } \\
\text { informasi yang disajikan } \\
\text { dalam neraca, yang } \\
\text { menghilangkan pos: } \\
\text { - } \text { Aset keuangan } \\
\text { - } \text { Properti investasi } \\
\text { yang diukur pada nilai } \\
\text { wajar (ED PSAK 1) } \\
\text { - Aset biolojik yang } \\
\text { diukur pada biaya } \\
\text { perolehan dan nilai } \\
\text { wajar (ED PSAK 1) } \\
\text { - Kewajiban berbunga } \\
\text { jangka panjang } \\
\text { - Aset dan kewajiban } \\
\text { pajak tangguhan } \\
\text { Kepentingan } \\
\text { nonpengendalian }\end{array}$ \\
\hline 2 & Laporan Laba Rugi & $\begin{array}{l}\text { - Laporan laba rugi } \\
\text { komprehensif } \\
\circ \quad \text { Informasi yang } \\
\text { disajikan dalam } \\
\text { laporan Laba Rugi } \\
\text { Komprehensif } \\
\circ \quad \text { Laba rugi selama } \\
\text { periode }\end{array}$ & $\begin{array}{l}\text { Tidak sama dengan PSAK } \\
\text { yang menggunakan } \\
\text { istilah laporan laba } \\
\text { rugi komprehensif, SAK } \\
\text { ETAP menggunakan istilah } \\
\text { laporan laba rugi. }\end{array}$ \\
\hline
\end{tabular}




\begin{tabular}{|c|c|c|c|}
\hline & & $\begin{array}{ll} & \text { Pendapatan } \\
\text { komprehensif lain } \\
\text { selama periode } \\
\text { Informasi yang } \\
\text { disajikan dalam } \\
\text { laporan laba rugi } \\
\text { komprehensif atau } \\
\text { catatan atas laporan } \\
\text { keuangan }\end{array}$ & \\
\hline 3 & $\begin{array}{l}\text { Penyajian Perubahan } \\
\text { Ekuitas }\end{array}$ & & $\begin{array}{l}\text { Sama dengan PSAK, kecuali } \\
\text { untuk beberapa hal yang } \\
\text { terkait pendapatan } \\
\text { komprehensif lain. }\end{array}$ \\
\hline 4 & $\begin{array}{l}\text { Catatan Atas } \\
\text { Laporan Keuangan }\end{array}$ & $\begin{array}{ll}\text { - } & \text { Catatan atas laporan } \\
& \text { keuangan } \\
\text { - } & \text { Struktur } \\
\text { - } & \text { Pengungkapan kebijakan } \\
& \text { Akuntansi } \\
\text { - } & \text { Sumber estimasi } \\
& \text { ketidakpastian } \\
\text { - } & \text { Modal (ED PSAK 1) } \\
\text { - } & \text { Pengungkapan lain }\end{array}$ & $\begin{array}{l}\text { Sama dengan PSAK, kecuali } \\
\text { pengungkapan modal. }\end{array}$ \\
\hline 5 & Laporan Arus Kas & $\begin{array}{l}\text { - } \text { Arus kas aktivitas operasi: } \\
\text { metode langsung dan tidak } \\
\text { langsung } \\
\text { - } \quad \text { Arus kas aktivitas investasi } \\
\text { - } \text { Arus kas aktivitas pendanaan } \\
\text { - } \text { Arus kas mata uang asing } \\
\text { - } \text { Arus kas bunga dan dividen, } \\
\text { pajak penghasilan, transaksi } \\
\text { non-kas }\end{array}$ & $\begin{array}{l}\text { Sama dengan PSAK kecuali: } \\
\text { - } \quad \text { Arus kas aktivitas } \\
\text { operasi: metode tidak } \\
\text { langsung } \\
\text { - } \begin{array}{l}\text { Arus kas mata uang } \\
\text { asing, tidak diatur. }\end{array} \\
\end{array}$ \\
\hline 6 & $\begin{array}{l}\text { Laporan } \\
\text { keuangan konsolidasi } \\
\text { dan terpisah }\end{array}$ & $\begin{array}{ll}\text { - } & \text { Persyaratan penyajian lapkeu } \\
& \text { konsolidasi } \\
\text { - Entitas bertujuan khusus } \\
\text { - Prosedur konsolidasi } \\
\text { - Lapkeu tersendiri } \\
\text { - Lapkeu gabungan }\end{array}$ & Tidak diatur (Lihat Bab 12). \\
\hline 7 & $\begin{array}{l}\text { Kebijakan } \\
\text { akuntansi, estimasi, } \\
\text { dan kesalahan }\end{array}$ & 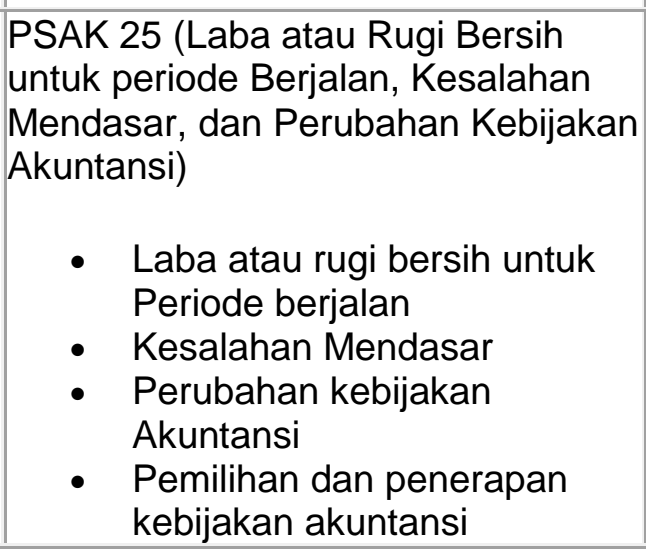 & $\begin{array}{l}\text { SAK ETAP sudah maju satu } \\
\text { langkah dibandingkan PSAK } \\
\text { (tidak ada "kesalahan } \\
\text { mendasar" dan "laba atau } \\
\text { rugi luar biasa"). }\end{array}$ \\
\hline
\end{tabular}




\begin{tabular}{|c|c|c|c|}
\hline & & $\begin{array}{ll}\text { - } & \text { Konsistensi dan perubahan } \\
\text { - } & \text { Pebijakan akuntansi } \\
& \text { akuntansi } \\
\text { - } & \text { Kesalahan. } \\
\text { - } & \text { Pos luar biasa } \\
\text { - } & \text { Laba atau rugi dari aktivitas } \\
\text { normal } \\
\text { - Operasi yang tidak } \\
\text { - } \text { dilanjutkan } \\
\text { Perubahan estimasi } \\
\text { - } \text { Akuntansi } \\
\text { - Akuntansi keuangan } \\
\text { - Perubahan kebijakan } \\
\text { Akuntansi yang lain }\end{array}$ & \\
\hline 8 & $\begin{array}{l}\text { Instrumen Keuangan } \\
\text { Dasar }\end{array}$ & $\begin{array}{l}\text { - } \quad \text { Ruang lingkup: aset dan } \\
\text { - } \quad \text { Instrajiban keuangan } \\
\text { - } \quad \text { Diklasifikasikan pada nilai } \\
\text { wajar melalui laporan laba } \\
\text { rugi, dimiliki hingga jatuh } \\
\text { tempo, tersedia untuk dijual, } \\
\text { pinjaman dan pinjaman yang } \\
\text { diberikan } \\
\text { - } \quad \text { Impairment menggunakan } \\
\text { incurred loss concept } \\
\text { - } \quad \text { Derecognition } \\
\text { - } \quad \text { Hedging dan derivatif } \\
\text { - } \text { Ruang lingkup: investasi } \\
\text { - } \quad \text { Kada efek tertentu } \\
\text { maturitasi trading, held to } \\
\text { sale. Hal tsb mengacu me }\end{array}$ & PSAK 50 (1998). \\
\hline 9 & Persediaan & $\begin{array}{l}\text { - } \text { Pengukuran persediaan } \\
\text { - } \text { Biaya persediaan } \\
\text { - } \text { Biaya pembelian } \\
\text { - } \text { Biaya konversi } \\
\text { - } \text { Biaya persediain } \\
\quad \text { jasa } \\
\text { - } \text { Teknik pengukuran biaya } \\
\text { - } \text { Rilai realisasi bersih } \\
\text { - Pengakuan sebagai beban } \\
\text { - Pengungkapan }\end{array}$ & Sama dengan PSAK \\
\hline 10 & $\begin{array}{l}\text { Investasi } \\
\text { pada perusahaan } \\
\text { asosiasi dan entitas } \\
\text { anak }\end{array}$ & $\begin{array}{l}\text { - } \text { Ruang lingkup: entitas } \\
\text { - } \text { Mesosiasi } \\
\text { - } \text { Metode akuntansi } \\
\text { - } \quad \text { Metode biaya } \\
\end{array}$ & metode ekuitas \\
\hline
\end{tabular}




\begin{tabular}{|c|c|c|c|}
\hline & & $\begin{array}{l}\text { - } \text { Model nilai wajar (ED PSAK } \\
\text { 15) } \\
\text { - } \quad \text { Ruang lingkup: entitas } \\
\text { asosiasi dan entitas anak } \\
\text { - } \text { Metode akuntansi } \\
\text { - Entitas asosiasi : metode } \\
\text { biaya } \\
\text { - Entitas anak: }\end{array}$ & \\
\hline 11 & $\begin{array}{l}\text { Investasi } \\
\text { pada perusahaan } \\
\text { asosiasi dan entitas } \\
\text { anak }\end{array}$ & $\begin{array}{ll}\text { - } & \text { Jointly controlled operation, } \\
& \text { asset, and entity } \\
\text { - } & \text { Metode akuntansi } \\
\text { - } & \text { Metode konsolidasi } \\
& \text { proporsional } \\
\text { - } & \text { Metode ekuitas } \\
\text { - } & \text { Model nilai wajar (ED PSAK } \\
& 12: \text { PBA/PBO/PBE) }\end{array}$ & $\begin{array}{l}\text { Sama dengan PSAK kecuali } \\
\text { metode akuntansi hanya } \\
\text { menggunakan metode biaya. }\end{array}$ \\
\hline 12 & Property Investasi & $\begin{array}{l}\text { Metode akuntansi } \\
\text { - Model nilai wajar } \\
\text { Model biaya }\end{array}$ & Metode akuntansi: model biaya \\
\hline 13 & Aset Tetap & $\begin{array}{ll}\text { - } & \text { Menggunakan pendekatan } \\
\text { - } & \text { Pempongukuran mengaunakan } \\
& \text { model biaya atau model } \\
& \text { revaluasi } \\
\text { - } & \text { Pengukuran biaya perolehan } \\
\text { - } & \text { Pengakuan pengeluaran } \\
\text { - } & \text { Pelanjutnya } \\
\text { - } \text { Tidak perlu review nilai } \\
\text { residu, metode penyusutan, } \\
\text { dan umur manfaat setiap } \\
\text { akhir periode pelaporan, } \\
\text { tetapi jika ada indikasi } \\
\text { perubahan saja }\end{array}$ & $\begin{array}{l}\text { Sama dengan PSAK kecuali: } \\
\text { - } \quad \text { Tidak menggunakan } \\
\text { pendekatan } \\
\text { komponenisasi. } \\
\text { - Revaluasi diijinkan jika } \\
\text { dilakukan berdasarkan } \\
\text { Peraturan Pemerintah. } \\
\text { Hal ini mengacu ke PSAK } \\
16(1994) \\
\text { - Tidak perlu review nilai } \\
\text { residu. }\end{array}$ \\
\hline \multirow[t]{2}{*}{14} & Asset Tidak Berwujud & $\begin{array}{l}\text { - Prinsip umum untuk } \\
\text { - Pengakuan } \\
\text { Pengakuan awal, pengukuran } \\
\text { - } \text { Amolanjutnya } \\
\text { manfisaat atau } 10 \text { tahun } \\
\text { Penurunan nilai }\end{array}$ & $\begin{array}{l}\text { Sama dengan PSAK, kecuali } \\
\text { aset tidak berwujud yang } \\
\text { diperoleh dari penggabungan } \\
\text { usaha. }\end{array}$ \\
\hline & & $\begin{array}{l}\text { - Menggunakan metode } \\
\text { pembelian } \\
\text { - Goodwill dimaortisasi } 5 \text { tahun } \\
\text { atau } 20 \text { tahun dengan } \\
\text { justifikasi manajemen }\end{array}$ & Tidak diatur \\
\hline
\end{tabular}




\begin{tabular}{|c|c|c|c|}
\hline 15 & Sewa & $\begin{array}{l}\text { - } \text { Mengatur perjanjian yang } \\
\text { mengandung sewa } \\
\text { - Klasifikasi bersifat principle } \\
\text { based } \\
\text { - Laporan keuangan lessee } \\
\text { dan } \\
\text { - Tidak mengatur perjanjian } \\
\text { yang mengandung sewa } \\
\text { (ISAK) }\end{array}$ & \\
\hline & & lessor & $\begin{array}{l}\text { - Klasifikasi sewa: } \\
\text { kombinasi IFRS for SMEs } \\
\text { dan SFAS } 13 \\
\text { - } \quad \text { Laporan keuangan lessee } \\
\text { dan lessor menggunakan } \\
\text { PSAK } 30 \\
\text { (1990): Akuntansi } \\
\text { SewaGuna Usaha }\end{array}$ \\
\hline & & $\begin{array}{ll}\text { - } & \text { Kewajiban diestimasi } \\
\text { - } & \text { Kewajiban kontinjensi } \\
\text { - } & \text { Aset kontinjensi }\end{array}$ & Sama dengan PSAK \\
\hline 16 & Ekuitas & $\begin{array}{ll}\text { - } & \text { Penjelasan } \\
\text { - } & \text { Akuntasi ekuitas untuk badan } \\
& \text { usaha bukan PT } \\
\text { - } & \text { Akuntansi ekuitas untuk } \\
& \text { badan usaha berbentuk PT } \\
\text { - Reorganisasi } \\
\text { - Selisih penilaian kembali }\end{array}$ & $\begin{array}{l}\text { Sama dengan PSAK, kecuali : } \\
\text { - } \text { Reorganisasi } \\
\text { - } \\
\text { Selisih penilaian kembali }\end{array}$ \\
\hline 17 & Pendapatan & $\begin{array}{ll}\text { - } & \text { Penjualan barang } \\
\text { - } & \text { Penjualan jasa } \\
\text { - } & \text { Kontrak konstruksi } \\
\text { - } & \text { Bunga, dividen dan royalti } \\
\text { - } & \text { Lampiran kasus } \\
& \text { pengakuan pendapatan (ED } \\
& \text { PSAK 23) }\end{array}$ & Sama dengan PSAK. \\
\hline 18 & Biaya Pinjaman & $\begin{array}{l}\text { - Komponen biaya pinjaman } \\
\text { - Pengakuan dan kapitalisasi } \\
\text { biaya pinjaman }\end{array}$ & $\begin{array}{l}\text { Biaya pinjaman langsung } \\
\text { dibebankan }\end{array}$ \\
\hline 19 & Penurunan Nilai Aset & $\begin{array}{l}\text { - Penurunan nilai persediaan } \\
\text { - } \quad \text { Penurunan nilai non- } \\
\text { - Persediaan } \\
\text { - Penurunan nilai goodwill }\end{array}$ & $\begin{array}{l}\text { Sama dengan PSAK, kecuali: } \\
\begin{array}{l}\text { - } \\
\text { Ruang lingkup yang } \\
\text { meliputi semua jenis aset. } \\
\text { - } \text { Tidak mengatur } \\
\text { penurunan nilai goodwill }\end{array}\end{array}$ \\
\hline
\end{tabular}




\begin{tabular}{|c|c|c|c|}
\hline & & & $\begin{array}{l}\text { - Ada tambahan penurunan } \\
\text { nilai untuk pinjaman yang } \\
\text { diberikan dan piutang } \\
\text { yang menggunakan } \\
\text { PSAK } \\
\text { 31:AkuntansiPerbankanp } \\
\text { aragraf } 16 \text { dan } 17 .\end{array}$ \\
\hline 20 & Imbalan Kerja & $\begin{array}{l}\text { - Imbalan kerja jangka pendek } \\
\text { - Imbalan pasca kerja, untuk } \\
\text { manfaat pasti menggunakan } \\
\text { PUC } \\
\text { - Imbalan jangka panjang } \\
\text { lainnya }\end{array}$ & $\begin{array}{l}\text { Sama dengan PSAK, kecuali } \\
\text { untuk manfaat pasti } \\
\text { menggunakan PUC dan jika tidak } \\
\text { bisa, menggunakan metode yang } \\
\text { disederhanakan }\end{array}$ \\
\hline 21 & Pajak Penghasilan & $\begin{array}{l}\text { - } \text { Menggunakan deferred } \\
\text { taxconcept } \\
\text { - Pengakuan dan pengukuran } \\
\text { pajak kini } \\
\text { - Pengakuan dan pengukuran } \\
\text { pajak tangguhan } \\
\text { - Menggunakan tax payable } \\
\text { concept } \\
\text { Tidak ada pengakuan } \\
\text { danpengukuran } \\
\text { pajak tangguhan }\end{array}$ & \\
\hline 22 & $\begin{array}{l}\text { Mata Uang } \\
\text { Pelaporan }\end{array}$ & $\begin{array}{l}\text { - } \quad \text { Mata uang pencatatan dan } \\
\text { - } \quad \text { Mata uanoran } \\
\text { - } \quad \text { Penentuan saldo awal } \\
\text { - } \quad \text { Penyajian komparatif } \\
\text { - } \quad \text { Perubahan mata uang } \\
\quad \text { pencatatan dan pelaporan }\end{array}$ & $\begin{array}{l}\text { Sama dengan PSAK Mata Uang } \\
\text { Pelaporan } \\
\begin{array}{ll}\text { - } & \text { Mata uang fungsional } \\
\text { - } & \text { Pelaporan transaksi mata } \\
& \text { uang asing dalam mata } \\
\text { uang fungsional } \\
\text { - } & \text { Perubahan mata uang } \\
\text { fungsional (Pada } \\
\text { prinsipnya sama) }\end{array}\end{array}$ \\
\hline 23 & $\begin{array}{l}\text { Peristiwa setelah } \\
\text { akhir periode } \\
\text { pelaporan }\end{array}$ & $\begin{array}{l}\text { - Peristiwa yang memerlukan } \\
\text { penyesuaian } \\
\text { - Peristiwa yang tidak } \\
\text { memerlukan penyesuaian }\end{array}$ & Sama dengan PSAK \\
\hline 24 & $\begin{array}{l}\text { Pengungkapan } \\
\text { pihak-pihak yang }\end{array}$ & $\begin{array}{l}\text { - Pengertian pihak-pihak yang } \\
\text { mempunyai hubungan }\end{array}$ & Sama dengan PSAK 7 \\
\hline
\end{tabular}




\begin{tabular}{|c|c|c|c|}
\hline & $\begin{array}{l}\text { mempunyai hubunga } \\
\mathrm{n} \text { istimewa }\end{array}$ & $\begin{array}{ll} & \text { istimewa } \\
\text { - } & \text { Pengungkapan }\end{array}$ & \\
\hline 25 & Aktivitas Khusus & $\begin{array}{l}\text { - Akuntansi perkoperasian } \\
\text { - } \quad \text { Akuntansi minyak dan gas } \\
\text { bumi } \\
\text { - } \text { Akuntansi pertambangan } \\
\text { - } \text { umum } \\
\text { - Akuntansi perusahaan efek } \\
\text { - Akuntansi reksa dana } \\
\text { Asuntansi perbankan dan } \\
\text { asuransi }\end{array}$ & Tidak diatur \\
\hline 26 & Ketentuan Transisi & & $\begin{array}{l}\text { - Retrospektif atau } \\
\text { prospektif (jika tidak } \\
\text { praktis) yang diterapkan } \\
\text { secara prospective } \\
\text { catchup (dampak ke saldo } \\
\text { laba) } \\
\text { - Perpindahan dari dan ke } \\
\text { SAK ETAP }\end{array}$ \\
\hline 27 & Tanggal Efektif & & $\begin{array}{l}\text { Berlaku efektif untuk laporan } \\
\text { keuangan yang dimulai pada } \\
\text { tanggal } 1 \text { Januari } 2011, \\
\text { penerapan dini } 1 \text { Januari } 2010\end{array}$ \\
\hline
\end{tabular}

Dikutip dari keuangan Ism.com 


\section{Simpulan}

Berdasarkan tujuan, hasil penelitian serta pembahasan dari penelitian ini, maka kasimpulan yang dapat diambil adalah sebagai berikut :

1. SAK ETAP merupakan SAK yang digunakan untuk entitas yang tidak memiliki akuntabilitas atau pertanggungjawaban publik, karena dari sisi permodalan dan tanggung jawab tidak menyertakan kepentingan publik. Hal itu mempengaruhi penyajian dan pengungkapan laporan yang lebih sederhana dibandingkan dengan laporan entitas yang menggunakan SAK IFRS.

2. Dalam pelaksanaan standar audit dengan penggunaan SAK ETAP sebagai pembanding, prosedur dan program yang dugunakan relatif tetap sama dengan standar audit yang tertuang di SPAP (Standar Profesi Akuntan Publik) yang biasanya digunakan juga sebagai standar audit untuk entitas yang menggunakan SAK IFRS, hanya saja dengan adanya kesimpulan pertama, maka secara otomatis dalam pelaksanaan program dan prosedurnya akan lebih sederhana karena akan disesuaikan dengan penyajian dan tujuan auditnya.

3. Terdapat beberapa penyesuaian yang telah dibahas dalam pembahasan sebelumnya, terutama dari sisi unsur dan isi SAK ETAP yang tidak serumit dan lebih sederhana daripada SAK IFRS, contoh dalam penyajian PSAK IFRS no.46 tentang Akuntansi Pajak Penghasilan dan PSAK IFRS no.24 tentang manfaat pensiun. Pada SAK ETAP tidak diwajibkan untuk menggunakan perhitungan dan penyajian dua PSAK tersebut, sehingga dalam penyajiannya tidak diperlukan, yang mana hal tersebut akan mempengaruhi program dan prosedur audit yang digunakan.

\section{DAFTAR PUSTAKA}

Abdolmohammadi, M., and A. Wrigth. 1997. An examination of the effects of experience and task complexity on audit judgments. The Accounting Review 62(1): 1-13.

Alderman, C.W., and J.W. Deltrick. 1982. Auditors' perceptions of time budget pressures and premature sign-offs: A replication and extension. Auditing: A Journal of Practice \& Theory (Winter): 54-68.

Anderson, J. C., D.J. Lowe, and P. M. J. Reckers. 1993. Evaluation of auditor decisions: Hindsight bias effects and the expectation gap. Journal of Economic Psychology 14 (4): 711-737.

Anderson, J. C., M. M. Jennings, D. J. Lowe, and P. M. J. Reckers. 1997. The mitigation of hindsight bias in judges' evaluation of auditor decisions. Auditing: A Journal of Practice \& Theory 16 (fall): 20-39. 
Aranya, N., and K.R. Ferris. 1984. An examination of accountants' organizationalproffesional conflict. The Accounting Review (January): 1-15.

Arens, Alvin A. \& James K. Loebecke, 1991, Auditing, Prentice-Hall, Inc, Simon-Schuster Company, New Jersey.

Ashton, R. H. 1982. Human Information Processing in Accounting, Studies in Accounting Research No. 17 (Sarasota, FL: AAA).

Ashton, R. H., and S. S. Kramer. 1980. Students as surrogates in behavioral accounting research: some evidence. Journal of Accounting Research 18 (1): 1-15.

Bamber, E. M., D. Snowball, and R. M. Tubbs. 1989. Audit structure and its relation to role conflict and role ambiguity: An empirical investigation. The Accounting Review (April): 285-299.

Bamber, E. Michael \& Robert. J. Ramsey, 2000, The Effects of Specializationin Audit Workpaper Review on Review Efficiency and Reviewers' Confidence, Auditing : A Journal of Practice \& Theory Vol. 19 No. 2.

Bedard, J., and M. T. H. Chi. 1993. Expertice in auditing. Auditing: A Journal of Practice \& Theory 12 (Supplement): 21-45.

Beets, S. D., and L. N. Killough. 1990. The effectiveness of a complaint-based ethics enforcement system: Evidence from the accounting proffesion. Journal of Business Ethics (February): 115-126.

Berrel, G. Dan G. Morgan. 1979. Sociological Paradidms and Organisational Analysis. Ashgate Publishing Company, USA.

Biggs, S. F., W. F. Messier, and J. V. Hansen. 1987. A descriptive analysis of computer audit specialists' decision-making behavior in advanced computer environments. Auditing: A Journal of Practice \& Theory 6 (Spring): 1-21.

Blau, G.J. 1988. Further exploring the meaning and measurement of career commitment. Journal of Vocational Behaviour. 284-297.

Bonner, S. E, and B. L. Lewis. 1990. Determinants of auditor expertice. Journal of Accounting Research 28 (Supplement): 1-20.

Bonner, S. E, and N. Pennington. 1991. Cognitive proecesses and knowledge as determinants of auditor expertice. Journal of Accounting Literature 10: 1-50.

Bonner, S. E, R. Libby and M. W. Nelson. 1996. Using decision aids to improve auditor's conditional probability judgments. The Accounting Review 71 (April): 221-240.

Bonner, S. E. 1990. Experience effects in auditing: The role of task-specific knowledge. The Accounting Review 65 (January):72-92.

Bonner, S. E. 1991. Is experience necessary in cue measurement? The case of auditing tasks. Contemporary Accounting Research 8(1): 253-269.

Boynton, William C \& Walter G. Kell, 2008, Modern Auditing 11th Edition, John Wiley and Sons. 
Brazel, J. F., C. P. Agoglia, and R. C. Hatfield. 2004. Electronic vs. Face-to-face review: The effects of alternative forms of review on auditors' perfomance. The Accounting Review 79 (October): 949-966.

Brown, J. L., and K. M. Johnstone. 2004. Effects of engagement risk and auditor experience on the process and outcomes of client-auditor negotiation. Working paper, University of Wisconsin-Madison.

Bryan-Low, C. 2002. Andersen witness packs big punch. The Wall Street Journal 3 June 2002.

Buchman, T. A., and J. A. Tracy. 1982. Obtaining responses to sensitive questions: Conventional questionnaire versus randomized response technique. Journal of Accounting Research (Spring): 263-271.

Choo, F. 1986. Job stress, job perfomance, and auditor personality characteristics. Auditing: Journal of Practice \& Theory. (Spring): 17-34.

Chow, C. W. L. Kramer, and W. A. Wallace. 1988. The environment of auditing. In Research Opportunities in Auditing: The Second Decade, edited by A. R. Abdel-Khalik and I. Solomon, 155-183. Sarasota, FL: AAA.

Crowne, D. P., and D. Marlowe. 1964. The Approval Motive: Studies in Evaluative Dependence. New York, NY: John Wiley \& Sons.

Cushing, B. E. 1989. Discussion of the association between audit technology and audit delay, Auditing: A Journal of Practice \& Theory (Supplement): 38-47.

Cushing, B. E. and J. K. Loebbecke. 1986. Comparison of audit methodologies of large accounting firms. Studies in Accounting Research \#26. Sarasota, FL: AAA.

Dando, C. \& Watson, R., "Women in Accounting", Australian Accountant, Vol. 56, November 1986, pp. 12-18.

Day, D. V., and S. B. Silverman. 1989. Personality and job performance: Evidence of incremental validity. Personnel Psycology 42: 25-36.

Effendy, Rustam, 2001, Dasar-dasar Manajemen Modern edisi ke-3, Jurusan Manajemen FE-UB.

Einhorn, H. J. 1972. Alchemy in the behavioral sciences. Public Opinion Quartely 36 (Fall): 367-378.

Eining, M. M., D. R. Jones, and J. K. Loebbecke. 1997. Reliance on decision aids: An examination of auditors' assessment of management fraud. Auditing: A Journal of Practice \& Theory 16 (Fall): 1-19.

Farmer, T. A., L. E. Rittenberg, and G. M. Trompeter. 1987. An investigation of the impact of economic and organizational factors on auditor independence. Auditing: A Journal of Practice \& Theory 7 (Fall): 1-14.

Ferris, K. R. and D. F. Larcker. 1983. Explanatory variables of auditor performance in a large public accounting firm. Accounting, Organizations and Society: 1-11. 
Frederick, D. M. 1991. Auditors' representation and retrieval of internal control knowledge. The Accounting Review 66 (April): 240-258.

Frederick, D. M., and R. Libby. 1986. Expertise and auditors' judgments of conjunctive events. Journal of Accounting research 24 (Autumn): 270-290.

Frew,D. R., and N. S. Brunning. 1987. Perceived organizational characteristics and personality measure as predictors of stress/strain in the work place. Journal of Managemenet 13 (4): 633-646.

Gumnitz, B. R., T. R. Nunamaker, J. J. Surdick, and M. F. Thomas. 1982. Auditor Consensus internal control evaluation and audit program planning. Journal of Accounting Research 20 (Autumn, part II): 745-755.

Eining, M. M., D. R. Jones, and J. K. Loebbecke. 1997. Reliance on decision aids: An examination of auditors' assessment of management fraud. Auditing: A Journal of Practice \& Theory 16 (Fall): 1-19.

Farmer, T. A., L. E. Rittenberg, and G. M. Trompeter. 1987. An investigation of the impact of economic and organizational factors on auditor independence. Auditing: A Journal of Practice \& Theory 7 (Fall): 1-14.

Ferris, K. R. and D. F. Larcker. 1983. Explanatory variables of auditor performance in a large public accounting firm. Accounting, Organizations and Society: 1-11.

Frederick, D. M. 1991. Auditors' representation and retrieval of internal control knowledge. The Accounting Review 66 (April): 240-258.

Frederick, D. M., and R. Libby. 1986. Expertise and auditors' judgments of conjunctive events. Journal of Accounting research 24 (Autumn): 270-290.

Frew,D. R., and N. S. Brunning. 1987. Perceived organizational characteristics and personality measure as predictors of stress/strain in the work place. Journal of Managemenet 13 (4): 633-646.

Gumnitz, B. R., T. R. Nunamaker, J. J. Surdick, and M. F. Thomas. 1982. Auditor Consensus internal control evaluation and audit program planning. Journal of Accounting Research 20 (Autumn, part II): 745-755.

Gibbins S and. McCracken and S. Salterio. 2004. Negotiations over accounting issues: The congruency of audit partner and chief financial officerrecalls. Working paper, Universities of Toronto and Alberta and Queen's University.

Gibbins, and K. T. Trotman. 2002. Audit review: Managers' interpersonal expectations and conduct of the review. Contemporary Accounting Research 19 (Fall): 411-444.

Gibbins, and S. Q. Qu. 2005. Eliciting experts' context knowledge with theory-based experiential questionnaires. Behavioral Research in Accounting, forthcoming.

Glover, H., Mynatt, P. G. and Schroeder, R. G., "The personality, job Satisfaction and Turnover Intentions of African-American Male and Female: Accountants: An Examination of the Human Capital and Structural/Class Theories", Critical Perspectives on Accounting, 1999, Forthcoming. 
Harrel, A., E. Chewning, and M. Taylor. 1986. Organizational-proffesional conflict and the job satisfaction and turnover intentions of internal auditors. Auditing: A Journal of Practice \& Theory 5 (Spring): 109-121.

Hollenbeck, J. R., and A. P. Brief. 1987. The effect of individual differences and goal origin on goal setting and performance. Organizational Behaviour and Human Decision Processes: 392-414.

Hyatt, T. A., and D. F. Prawitt. 2001. Does congruence between audit structure and auditors' locus of control affect job performance? The Accounting Review 76(2): 263-274.

Ikatan Akuntan Indonesia Kompartemen Akuntan Publik (IAI-KAP), 2001, Standar Profesional Akuntan Publik, Penerbit Salemba Empat, Jakarta.

Ikatan Akuntan Indonesia Kompartemen Akuntan Publik, Mei 2009, Standar Akuntansi Keuangann - Entitas Tanpa Akuntabilitas (SAK-ETAP).

Ivancevich, J. M., and M. T. Matteson. 1987. Organizational Behaviour and Management. Plano, TX: BPI.

Jackson, D. N. 1989. Personality Research Form Manual. New York, NY: Research Psycologists Press.

Jennings, M., D. C. Kneer, and P. M. J. Reckers. 1987. A reexamination of the concept of materiality: Views of the auditors, users, andofficers of the court. Auditing: A Journal of Practice \& Theory 6 (Spring): 104-115.

Jensen, K. 2004. The effect of conflicting pressures on auditors' resolution of ambiguous audit issues. Working paper, University of Oklahoma.

Johnson, V. E., S. E. Kaplan. 1991. Experimental evidence on the effects of accountability on auditors' judgments. Auditing: A Journal of Practice \& Theory 10 (Supplement): 96-107.

Kachelmeier, S. J., and W. F. Messier, 1990. An investigation of the influence of a nonstatistical decision aid on auditor sample size decisions. The Accounting Review 65 (January): 209-226.

Kadous, K. 2000. The effects of audit quality and consequence severity on juror evaluation of auditor responsibility for plaintiff losses. The Accounting Review 75 (July): 327341.

Kaplan, S. E. 1985. An examination of the effects of environment and explicit internal control evaluation on planned audit hours. Auditing: A Journal of Practice \& Theory 5 (Fall): 12-25.

Kaplan, S. E., and P. M. J. Reckers. 1984. An empirical examination of auditors' initial planning processes. Auditing: A Journal of Practice \& Theory 4 (Fall): 1-19.

Kelley, T., and L. Margheim. 1990. The impact of time budget pressure, personality, and leadership variables on dysfunctional auditor behavior. Auditing: A Journal of Practice \& Theory 9 (Spring): 21-42. 
Kennedy, J. D. N. kleinmuntz, and M. E. Peecher. 1997. Determinants of the justifiability of performance on ill-structured audit tasks. Journal of Accounting Research 35 (Supplement): 105-123.

Kennedy, J. 1993. Debiasing audit judgment with accountability: A framework and experimental result. Journal of Accounting Research 31 (Autumn): 231-245.

King, R. R. 2002. An experimental investigation of self-serving biases in an auditing trust game: the effect of group affiliation. The Accounting Review 77 (April): 265-284.

Kinney, W. R, and M. W. Nelson. 1996. Outcome information and the "expectation gap": The case of loss contingencies. Journal of Accounting Research 34 (Autumn): 281-299.

Koonce, L. and, U. Anderson, and G. Marchant. 1995. Justification of decisions in auditing. Journal of Accounting Research 33 (Autumn): 369-384.

Krogstad, J. L., R. T. ettenson, and J. Shanteau. 1984. Context and experience in auditors' materiality judgments. Auditing: A Journal of Practice \& Theory 4 (Fall): 54-74.

Libby, R, and K. T. Trotman.1993. Determinants of judgment performance in accounting settings: Ability, knowledge, motivation, and environment. Accounting, Organizations and Society 18 (5): 425-450.

Libby, R, and P. A. Libby. 1989. Expert measurement and mechanical combinationin control reliance decisions. The Accounting Review 64 (October): 729-747.

Libby, R, and W. R. Kinney.2000. does mandated audit communiation reduce opportunistic corrections to manage earnings to forecast? The Accounting Review 75 (4): 383-404.

Libby, R. 1995. The role of knowledge and memory in audit judgment. In Judgment and Decisions-Making Research in Accounting and Auditing, edited by R. H. Ashton and A. H. Ashton. Cambridge, MA: Cambridge University Press.

Libby, R, and, J. T. Artman, and J. J. Willingham. 1985. Process susceptibility,control risk, and audit planning. The Accounting Review 60 (April): 212-230.

Libby, R.. 1981. Accounting and Human Information Processing: Theory and Applications. Englewood Cliffs, NJ: Prentice-Hall.

Lightner, S. M., S. J. Adams, and K. M. Lightner.1982. The influence of situational, ethical, and expectancy theory variables on accountants' underreporting behavior. Auditing:A Journal of Practice \& Theory 2 (Fall): 1-12.

Lord, A. T. 1992. Pressure: A methodological consideration for behavioral research in auditing. Auditing:A Journal of Practice \& Theory 11 (Fall): 89-108.

Low K. Y., 2004. The effects of industry specialization on audit risk assessments and auditplanning decisions, The Accounting Review 79(1):201-219.

Lowe, D. J., M. A. Geiger, and K. Pany. 1999. The effects of internal audit outsourcing on perceived external auditor indepence. Auditing:A Journal of Practice \& Theory 18 (Supplement):7-26. 
Lowe, D.J. and P. M. J. Reckers, and S. M. whitecotton. 2002. The effects of decision-aid use and reliability on jurors' evaluations of auditor liability. The Accounting Review 77 (January): 185-202.

Ludidgo. U. 2005. PEMAHAMAN STRUKTURISASI ATAS PRAKTIK ETIKA DI SEBUAH KANTOR AKUNTAN PUBLIK. RINGKASAN DISERTASI, 2005.

Maliki, Z. 2004. Agama Priyayi: Makna Agama di Tangan Penguasa. Pustaka Marwa. Yogyakarta.

Marchant, G. 1989. Analogical reasoning and hypothesis generation in auditing. The Accounting Review 64 (July): 500-513.

McDaniel, L. S. 1990. The effects of time pressure and audit program structure on audit performance. Journal of Accounting Research 28 (Autumn): 267-285.

Messier, W. F. 1995. Research in and development of audit-decision aids. In Judgment and Decision-making Research in Accounting and Auditing, edited by R. H. Ashton and A. H. Ashton. Cambridge, MA: Cambridge University Press.

Messier, W. F., and J. V. Hansen. 1987. Expet systems in auditing: The state of the art. Auditing: A Journal of Practice \& Theory 7 (Fall): 94-105.

Messier, W. F. and W. C. Quilliam. 1992. The effect of accountability on judgment: Development of hypotheses for auditing. Auditing: A Journal of Practice \& Theory 11 (Supplement): 123-138.

Messier, W. F. 1983. The effect of experience and firm type of materiality/disclosure judgments. Journal of Accounting Research 21(2): 611-618.

Muhajir, N. 2000. Metodologi Penelitian Kualitatif. Edisi IV. Penerbit Rake Sarasin, Yogyakarta.

Murtanto \& Gudono, 1999, Identifikasi Karakteristik-karakteristik Keahlian Audit : Profesi Akuntan Publik di Indonesia, Jurnal Riset Akuntansi Indonesia Vol.2:No.1, Januari 1999.

Nelson, M. 2004. Judgment and Decision Making Research in Auditing: A Task, person, and Interpersonal Interaction Perpective: Cornell University Hung-Tong Tan Nanyang Technological University, December 1, 2004.

Nelson, M. W. and J. A. Elliot, and R. L. Tarpley. 2002. Evidence from auditors about managers' and auditors' earnings management decisions. The Accounting Review 77 (Supplement): 175-202.

Nelson, M. W. and, J. A. Elliot, and R. L. Tarpley. 2003. How are earnings managed? Examples from auditors. Accounting Horizons 17 (Supplement): 17-35.

$\mathrm{Ng}$, T. B-P., and H. T. Tan. 2003. Effects of authoritative guidance availability and audit committee effectiveness on auditors' judgements in an auditor-client negotiation contect. The Accounting Review 78 (3): 801-818.

Owhoso, V. E., W. F. Messier, and J. G. Lynch. 2002. Error detection by industry-specialized teams during sequential audit review. Journal of Accounting Research 40 (Fall): 883900. 
Pany, K., and P. M. J. Reckers. 1984. Non-Audit services and auditor independence - a continuing problem. Auditing: A Journal of Practice \& Theory 3 (Spring): 89-97.

Peecher, M. E. 1996. The influence of auditors' justification processes on their decisions: A cognitive model and experimental evidence. Journal of Accounting Research 34 (Spring): 125-140.

Pincus, K. V. 1990. Auditor individual differences and fairness of presentation judgments. Auditing: A Journal of Practice \& Theory 9 (Fall): 150-166.

Polanyi, M. 2001. Kajian Tentang Manusia. Penerbit Kanisius. Yogyakarta.

Ponemon, Lawrence.A \& John P. Wendell, Judgmental Versus Random Sampling in Auditing: An Experimental Investigation, Auditing: A Journal of Practice \& Theory Vol. 14, 1995.

Preston, Alistair, 1986, Interactions and Arrangements in the Prosses of informing, Accounting and Organization Society, Vol. 11, No.6, Pergamon Journal Itd.

Ramsay, R. J. 1994. Senior/manajer differences in audit workpaper review performance. Journal of Accounting Research 32 (Spring): 127-135.

Ricchiute, D. N. 1999. The effect of audit seniors' decisions on working paper documentation and on partners' decisions. Accounting, Organizations and Society 24 (2): 155-172.

Rich, J. S. 1997b. Multi-auditor judgment/decision making research: A decade later. Journal of Accounting Literature 16: 86-126.

Rich, J. S. 2004. Reviewers' responses to expectations about the client and the preparer. The Accounting Review 79 (April): 497-517.

Sanchez, M. H., C. P. Agoglia, and R. C. Hatfield. The role of auditor strategy in auditorclient negotiations over propsed financial statement adjustments. Working paper, Rider University.

Sawarjuwono, Tjiptohadi, 2002, Metodologi penelitian akuntansi, manajemen dan bisnis: Penelitian Kritis Critical Paradigm (Habermasian)

Shankar, P. G., and H. T. Tan. 2004. Determinants of audit preparers' justifications. Working paper, Nanyang Technological University.

Simnett, Roger, and K. T. Trotman. 1989. Auditor versus model: Information choice and information processing. The Accounting Review 64(3): 514-528.

Smith, J.F., and T. Kida. 1991. Heuristics and biases: Expertise and task realism in auditing. Psychological Bulletin 109 (3): 472-489.

Solomon, I., 1987. Multi-auditor judgment?decision making research. Journal of Accounting Literature 6: 1-25.

Solomon, I., M. D. Shields, and O. R. Whittington. 1999. What do industry-spcialist auditors know? Journal of Accounting Research 37 (Spring): 191-208.

Spradley, James P, 1997, Metode Etnografi, PT, Tiara Wacana, Yogya 
Tan, H. T and A. Kao. 1999. Accountability effects on auditors' performance: The influence of knowledge, problem-solving ability, and task complexity. Journal of Accounting Research 37 (Spring): 209-224.

Tan, H. T and K. Jamal. 2001. Do auditors objectively evaluate their subordinates' work? The Accounting Review 76 (January): 99-110.

Tan, H. T and K. T. Trotman. 2004. Effects of auditors' Negotiation Strategy on Chief Financial Officers' Judgments. Working paper, Nanyang Technological University and University of New South Wales.

Tan, H. T and Yip-Ow, J. 2001. Are reviewers' judgments influenced by memo structure and conclitions documented in audit workpapers? Contemporary Accounting Research 18(4): 663-678.

Tan, H. T. 1995. Effects o expectations, prior involvement, and review awareness on memory for audit evidence and judgment. Journal of Accounting Research 33 (Spring): 113- 136.

Tan, H. T and R. Libby. 1997. Tacit managerial versus technical knowledge as determinants of audit expertise in the field. Journal of Accounting Research 35 (Spring):97-114.

Tan, H. T., 2001. Methodological issues in measuring knowledge effects. International Journal of Auditing 5 (November): 215-224.

Tan, Hung Tong \& Karim Jamal, 2001, Do Auditor Objectively Evaluate Their Subordinates Work?, The Accounting Review Vol. 76 No. 1

Taylor,M. H. 2000. The effects of industry specialization on auditors' inherent risk assessments and confidence judgments. Contemporary Accounting research 17 (4): 693-712.

Tetlock, P. E. 1983. Accountability and the perseverance of first impressions. Social Psychology Quartely 46 (December): 285-292.

Trisnaningsih, Sri \& Didik Ardiyanto, 2002, Pengaruh Komitmen Terhadap Kepuasan Kerja Auditor: Motivasi sebagai Variabel Intervening (Studi Empiris pada Kantor Akuntan Publik di Jawa Timur), Materi Simposium Nasional Akuntansi 5, Semarang 5-6 September 2002.

Trotman, K. T, A. Wright, and S. nWright. 2004. Auditor negotiation: An investigation of the efficacy of intervention methods. The Accounting Review (forthcoming).

Trotman, K. T. 1985. The review process and the accuracy of auditor judgments. Journal of Accounting Research 23 (Autumn): 740-752.

Trotman, K. T. 1985. The review process and the accuracy of auditor judgments. Journal of Accounting Research 23 (Autumn): 740-752.

Trotman, K. T., and P. W. Yetton. 1985. The effect of the review process on auditor judgments. Journal of Accounting Research 23 (Spring): 360-369.

Turner, C. W. 2001. Accountability demands and the auditors' evidence search strategy: The influence of reviewer preferences and the nature of the response (belief vs. action). Journal of Accounting Research 39 (December): 683-706. 
Velasquez, M. 2002. Business Ethics; Concept and cases. Person Education, Inc., Upper Saddle River, New Jersey.

Wagner, R. K., R. J. Stenberg. 1985. Practical intelligence in real-world pursuits: The role of tacit knowledge. Journal of Personality and Social Psychology 49(2): 436-458.

Whitecotton, S. M. 1996. The effect of experience and confidence on decision aid reliance: A causal model. Behavioral Research in Accounting (8): 194-216.

Wilks, T. J.2002. Predecisional distortion of evidence as a consequence of real-time audit review. The Accounting Review 77 (1): 51-71.

Wright, S., and A. M. Wright. 1997. The effect of industry experience on hypothesis generation and audit planning decisions. Behavioral Research in Accounting 9: 273294.

Yip-Ow J., and H. T. Tan. 2000. Effects of the preparess' justification on the reviewer's hypothesis generation and judgment in analytical procedures. Accounting, Organizations and Society 25 (2): 203-215.

Arens, A.A, Elder, R, J. A and Beasley, M.S. 2003. Auditing and Assurance Service: An Intergrated Approach. Ninth Edition. Prentice Hall. New Jersey.

Mautz, R.K., dan H.A Sharaf. 1985. The Philosophy of Auditing. American Accounting Association Monograph No. 6 Sarasota, FL: AAA.

Yusuf, Haryono (2001)

Mulyadi. 2002. Auditing. Jakarta: Salemba empat

http://www.iaiglobal.or.id/referensi/detail.php?catid=\&id=56. Diakses pada 28 Desember 2011. 